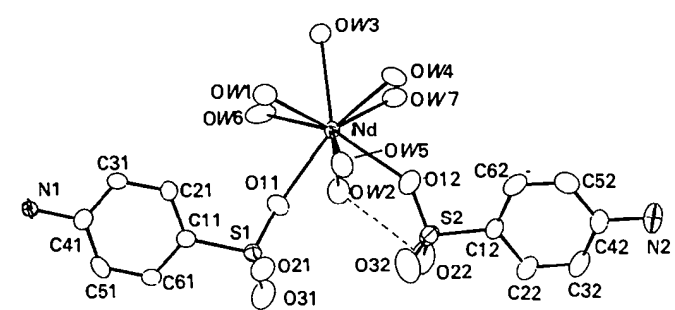

Fig. 1. The complex cation. The intramolecular hydrogen bond is marked with the dashed line. The numbering scheme of the third anion follows those of the two anions shown.

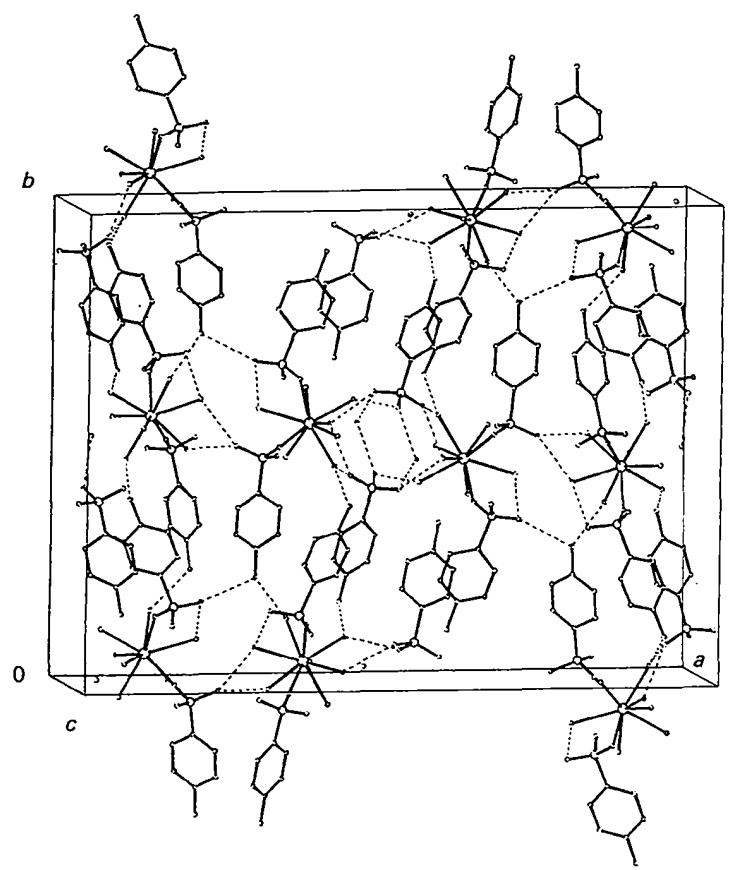

Fig. 2. View of the crystal structure. The dashed lines represent the hydrogen bonds. difference is in the lanthanide coordination number: eight for the quoted structures, and nine for the present one. All bond distances lie within observed ranges. The coordination polyhedron of $\mathrm{Nd} 1$ may best be described as a tricapped trigonal prism in which upper and lower bases are defined by 011 , $\mathrm{O} W 6, \mathrm{O} W 1$ and $012, \mathrm{O} W 7, \mathrm{O} W 4$ respectively, $\mathrm{O} W 2, \mathrm{O} W 3$ and $\mathrm{O} W 4$ being the caps; $\Delta=0.0063 \AA^{2}$ [ $\Delta=\sum d_{i}^{2} / 9$, where $d_{i}$ is the distance between the real position of the $i$ th atom and the relevant vertex in the ideal least-squares-fitted polyhedron (Drew, 1977)]. The two best capped square antiprisms found may be described as: (i) non-capped base $012, \mathrm{O} W 2$, O11, OW5; capped base OW7, OW6, OW1, OW4; cap OW3; $\Delta=0.0644 \AA^{2}$; and (ii) non-capped base OW2, OW7, OW3, OW6; capped base 012, OW4, $\mathrm{O} W 1, \mathrm{O} 11$; cap $\mathrm{OW5} \Delta=0.0522 \AA^{2}$. The structure is held together by an elaborate network of intermolecular hydrogen bonds. The crystal packing is shown in Fig. 2.

The author thanks Professor K. Bukietyńska for helpful discussion, and Professor T. Głowiak and Dr $\mathrm{T}$. Lis for help in performing the measurements.

\section{References}

Drew, M. G. B. (1977). Coord. Chem. Rev. 24, 179-275.

JOHNSON, C. K. (1976). ORTEPII. Report ORNL-5138. Oak Ridge National Laboratory, Tennessee, USA.

Ohki, Y., Suzuki, Y., Nakamura, M., Shimol, M. \& Ouchi, A. (1985). Bull. Chem. Soc. Jpn, 58, 2968-2974.

OHKI, Y., SuzUKI, Y., TakeuchI, T. \& OUChI, A. (1988). Bull. Chem. Soc. Jpn, 61, 393-405.

SHELDRICK, G. M. (1976). SHELX76. Program for crystal structure determination. Univ. of Cambridge, England.

SHELDRICK, G. M. (1986). SHELXS86. Program for the solution of crystal structures. Univ. of Göttingen, Germany.

Ugozzoli, F. (1987). Comput. Chem. 11, 109-120.

\title{
A Permethylcyclopentadienyl Carbollide Scandium Complex, $\mathrm{Sc}_{2} \mathrm{Si}_{4} \mathrm{O}_{3} \mathrm{C}_{50} \mathrm{~B}_{18} \mathrm{Li}_{2} \mathrm{H}_{114}$
}

\author{
By Richard E. Marsh, William P. Schaefer, Guillermo C. Bazan and John E. Bercaw \\ Divison of Chemistry and Chemical Engineering* and The Beckman Institute, Mail Code 139-74, \\ California Institute of Technology, Pasadena, California 91125, USA
}

(Received 3 July 1991; accepted 14 January 1992)

Abstract. Tris(tetrahydrofuran)lithium lithium bis[3bis(trimethylsilyl)methyl-3-( $\eta^{5}$-pentamethylcyclopen-

* Contribution No. 8430 .

0108-2701/92/081416-04\$06.00 tadienyl)-1,2-dicarba-3-scanda-closo-dodecaborate$(1-)], \quad\left[\mathrm{Li}\left(\mathrm{C}_{4} \mathrm{H}_{8} \mathrm{O}\right)_{3}\right] \cdot \mathrm{Li}\left[\mathrm{Sc}\left(\mathrm{C}_{2} \mathrm{~B}_{9} \mathrm{H}_{11}\right)\left(\mathrm{C}_{10} \mathrm{H}_{15}\right) \mathrm{CH}\{\mathrm{Si}-\right.$ $\left.\left.\left(\mathrm{CH}_{3}\right)_{3}\right\}_{2}\right]_{2}, M_{r}=1174.16$, triclinic, $P \overline{1}, a=8.924$ (4), $b=18.467$ (5), $c=22.165$ (3) $\AA, \alpha=91.42$ (2), $\beta=$

(C) 1992 International Union of Crystallography 
$92.36(2), \quad \gamma=92.21(3)^{\circ}, V=3645.6(18) \AA^{3}, Z=2$, $D_{x}=1.07 \mathrm{~g} \mathrm{~cm}^{-3}, \quad \lambda($ Mo $K \alpha)=0.71073 \AA, \quad \mu=$ $2.84 \mathrm{~cm}^{-1}, F(000)=1264$, room temperature, $294 \mathrm{~K}$, $R=0.064$ for 3069 reflections. Each $\mathrm{Sc}$ atom is bonded to one $\mathrm{Cp}^{*}$ in an $\eta^{5}$ fashion, to one carbollide ligand in an $\eta^{5}$ fashion (completing a distorted icosahedron), and to one $-\mathrm{CH}\left(\mathrm{SiMe}_{3}\right)_{2}$ group in the cleft; the angle at Sc subtended by the centers of the two $\eta^{5}$ groups is $137.8^{\circ}$. Two of these complexes share an Li atom which is loosely bonded to three B atoms of each carbollide, creating a dimeric monoanion. The counterion, a second $\mathrm{Li}$ atom, is coordinated to three tetrahydrofuran molecules.

Introduction. We have been studying various complexes of early-transition and lanthanide metals as catalysts for the classical homogeneous ZieglerNatta polymerization systems. We have found that neutral alkyl or hydride complexes of $\mathrm{Sc}$, such as $\left[\left\{\left(\eta^{5} \mathrm{C}_{5} \mathrm{Me}_{4}\right) \mathrm{Me}_{2} \mathrm{Si}\left(\eta^{1}-\mathrm{NCMe}_{3}\right)\right\} \mathrm{Sc}\left(\mathrm{PMe}_{3}\right)\right]_{2}(\mu-\mathrm{H})_{2}$, catalyze the polymerization or oligomerization of $\alpha$-olefins as well as the more facile polymerization of ethylene (Shapiro, Bunel, Schaefer \& Bercaw, 1990). However, these compounds are catalytically active only as monomers, whereas in solution the equilibria favor the dimers. In the hope of preventing this dimerization we have synthesized complexes of $\mathrm{Sc}$ containing the dianionic carbollide ligand $\left[\mathrm{C}_{2} \mathrm{~B}_{9} \mathrm{H}_{11}\right]$ as a substitute for the mono-anionic cyclopentadienyl or amide groups, since dimer formation would be discouraged by simple Coulombic repulsion. This carbollide ligand has recently been shown (Crowther, Baenzinger \& Jordan, 1991) to support $\alpha$-olefin polymerization or oligomerization catalytic activity in analogous neutral Group 4 complexes.

The carbollide ligand can be introduced either via the reaction of $\left[\mathrm{Cp}^{*} \mathrm{ScMe}_{2}\right]_{x}$ (Piers, Bunel \& Bercaw, 1991) with $\mathrm{C}_{2} \mathrm{~B}_{9} \mathrm{H}_{13}$ (Crowther, Baenzinger \& Jordan, 1991), followed by treatment with THF to yield $\mathrm{Cp}^{*}\left[\mathrm{C}_{2} \mathrm{~B}_{9} \mathrm{H}_{11}\right] \mathrm{Sc}(\mathrm{THF})_{3}$ or by the reaction of $\left[\mathrm{Cp}^{*} \mathrm{ScCl}_{2}\right]_{x}$ (Piers, Bunel \& Bercaw, 1991) with $\mathrm{Na}_{2}\left[\mathrm{C}_{2} \mathrm{~B}_{9} \mathrm{H}_{11}\right]$ (Manning, Knobler, Khattar \& Hawthorne, 1991), followed by addition of THF to yield the same product. Alkylation of $\mathrm{Cp}^{*}$ $\left[\mathrm{C}_{2} \mathrm{~B}_{9} \mathrm{H}_{11}\right] \mathrm{Sc}(\mathrm{THF})_{3}$ with $\mathrm{LiCH}(\mathrm{TMS})_{2}$ in toluene followed by precipitation in petroleum ether yields $\mathrm{Cp}^{*}\left[\mathrm{C}_{2} \mathrm{~B}_{9} \mathrm{H}_{11}\right] \mathrm{Sc}\left[\mathrm{CH}(\mathrm{TMS})_{2}\right] . \mathrm{Li}(\mathrm{THF})_{3}$. X-rayquality crystals of $\left[\mathrm{Cp}^{*}\left(\mathrm{C}_{2} \mathrm{~B}_{9} \mathrm{H}_{11}\right) \mathrm{ScCH}(\mathrm{TMS})_{2}\right]_{2}$ Li.Li(THF $)_{3}$ were obtained by pentane diffusion into a concentrated toluene solution of $\mathrm{Cp}^{*}\left[\mathrm{C}_{2} \mathrm{~B}_{9} \mathrm{H}_{11}\right] \mathrm{Sc}\left[\mathrm{CH}(\mathrm{TMS})_{2}\right]_{2} \mathrm{Li}(\mathrm{THF})_{3}$.

Experimental. Pale yellow crystal, flat needle, $0.17 \times$ $0.40 \times 1.30 \mathrm{~mm}$; CAD-4 diffractometer, $\omega$ scans; 24 reflections with $20<2 \theta<25^{\circ}$ for cell dimensions; no absorption correction $\left(\mu r_{\max }=0.19\right.$ and the two independent data sets merged well); $(\sin \theta / \lambda)_{\max }=$
$0.48 \AA^{-1} ; h$ from -8 to $8, k$ from -17 to $17, l$ from -21 to 21 ; three standard reflections (1114, 040, $\overline{1} 31)$ showed an early decay of about $3 \%$, then remained constant for the remainder of data collection; first 1164 reflections deleted from data set; 13754 reflections remained, 6801 of which were independent; goodness of fit for merging $=0.95 ; R_{\text {merge }}$ for 4195 reflections with exactly two observations $=6.4 \%$; all 6801 reflections used in solution and refinement; Sc atoms located with a Patterson map, remaining heavy atoms found by successive structure factor, difference Fourier cycles; $F^{2}$ values used in refinement with weights $w=1 / \sigma^{2}\left(F_{o}{ }^{2}\right) ; \mathrm{H}$ atoms on trimethylsilyl groups, tetrahydrofuran molecules and carbollide ligands placed by calculation with $\mathrm{C}-\mathrm{H}$ $=1.0, \mathrm{~B}-\mathrm{H}=1.05 \AA$, on $\mathrm{Cp}^{*}$ methyl groups at idealized positions based on difference maps calculated in the expected planes, isotropic $B$ values assigned based on displacement parameter of bonded atom; $\mathrm{H}$-atom parameters not refined, but atoms repositioned once before final least-squares cycles; coordinates of all heavy atoms refined, with anisotropic displacement parameters for $\mathrm{Sc}, \mathrm{Si}$, trimethylsilyl $\mathrm{C}$ atoms, $\mathrm{Cp}^{*}$ methyl $\mathrm{C}$ atoms and atoms of tetrahydrofuran; other $\mathrm{C}$ atoms, the $\mathrm{B}$ atoms and the $\mathrm{Li}$ atoms with isotropic thermal parameters, plus one scale factor, for a total of 532 parameters in one full matrix; final $R$ for 5812 reflections with $F_{o}^{2}>0$ was 0.128 , for 3069 reflections with $F_{o}^{2}>3 \sigma\left(F_{o}^{2}\right) R=$ $0.064, w R\left(\right.$ on $\left.F_{o}{ }^{2}\right)=0.013$, goodness of fit $=1.45$ for 6801 reflections and 532 parameters. Variances $\left[\sigma^{2}(I)\right]$ derived from counting statistics plus an additional term, $(0.014)^{2}$; variances of the merged data by propagation of error plus another additional term, $(0.014 \bar{l})^{2}$; ratio of maximum shift to e.s.d. in final least-squares cycle was 0.40 in a tetrahydrofuran $\mathrm{C}$ atom and 0.21 for other parameters; final difference Fourier map had excursions of 0.55 and $-0.65 \mathrm{e} \AA^{-3}$; atomic scattering factors and anomalous-dispersion corrections taken from Cromer \& Waber (1974) and Cromer (1974); computer programs used were those of the $C R Y M$ crystallographic computing system (Duchamp, 1964) and ORTEP (Johnson, 1976). Final parameters are given in Table 1 and selected distances and angles are listed in Table 2. $\dagger$ An ORTEPII drawing of the two anions and one $\mathrm{Li}$ atom showing the numbering system is shown in Fig. 1; Fig. 2 is a packing diagram.

† A figure showing the numbering system for the $\mathrm{Li}(\mathrm{THF})_{3}$ cation and lists of anisotropic displacement parameters, complete distances and angles, observed and calculated structure factors and assigned $\mathrm{H}$-atom parameters have been deposited with the British Library Document Supply Centre as Supplementary Publication No. SUP 55052 (40 pp.). Copies may be obtained through The Technical Editor, International Union of Crystallography, 5 Abbey Square, Chester $\mathrm{CH} 1 \mathrm{2HU}$, England. [CIF reference: HH0559] 
Table 1. Heavy-atom coordinates $\left(\times 10^{4}\right)$ and equivalent isotropic $\left(\AA^{2} \times 10^{4}\right)$ or isotropic $\left(\AA^{2}\right)$ thermal parameters for the $C p^{*}$ carbollide scandium complex

$$
U_{\text {eq }}=(1 / 3) \sum_{i} \sum_{j} U_{i j} a_{i}^{*} a_{j}^{*} \mathbf{a}_{i} \cdot \mathbf{a}_{j} .
$$

\begin{tabular}{|c|c|c|c|c|}
\hline & $x$ & $y$ & $z$ & $U_{\mathrm{cq}}$ or $B \dagger$ \\
\hline Scl & $3815(2)$ & 2298 (1) & $2181(1)$ & $503(5)$ \\
\hline $\mathrm{Sc} 2$ & 1785 (2) & 6797 (1) & 4013 (1) & $463(5)$ \\
\hline Sil & 5448 (3) & $1214(1)$ & 1029 (1) & $709(8)$ \\
\hline $\mathrm{Si} 2$ & 2320 (3) & $650(2)$ & 1455 (1) & 892 (10) \\
\hline $\mathrm{Si} 3$ & $220(3)$ & 8593 (1) & 4029 (1) & $771(10)$ \\
\hline Si4 & 3357 (3) & $8433(1)$ & $4684(1)$ & $789(9)$ \\
\hline $\mathrm{Cl}$ & 3992 (8) & $1261(4)$ & $1614(3)$ & $4.7(2) \dagger$ \\
\hline $\mathrm{C} 2$ & $1620(8)$ & 7964 (4) & $4351(3)$ & $4.3(2) \dagger$ \\
\hline Mel & $6862(9)$ & $1988(4)$ & $1094(4)$ & $862(30)$ \\
\hline $\mathrm{Me} 2$ & $4735(10)$ & $1208(6)$ & $232(4)$ & 1291 (43) \\
\hline $\mathrm{Me} 3$ & $6520(10)$ & $376(5)$ & $1094(5)$ & $1292(41)$ \\
\hline Me4 & $985(10)$ & $710(5)$ & $2082(4)$ & $1193(38)$ \\
\hline Me5 & $2713(11)$ & $-322(5)$ & $1396(6)$ & $1660(58)$ \\
\hline Me6 & $1198(10)$ & $835(6)$ & $749(4)$ & $1343(43)$ \\
\hline Me7 & $-1214(9)$ & $8146(4)$ & 3504 (4) & $984(32)$ \\
\hline Me8 . & -890 (11) & $9004(5)$ & 4641 (5) & $1552(45)$ \\
\hline Me9 & 933 (11) & $9368(5)$ & $3635(6)$ & $1911(60)$ \\
\hline Melo & $4653(9)$ & 7766 (5) & 5028 (4) & $975(33)$ \\
\hline Mell & 3044 (11) & $9074(6)$ & $5323(5)$ & $1543(44)$ \\
\hline Mel2 & $4479(10)$ & 8973 (4) & $4149(4)$ & $1103(38)$ \\
\hline $\mathrm{Cpl}$ & $5620(9)$ & $2714(4)$ & $3013(3)$ & $4.0(2) \dagger$ \\
\hline $\mathrm{Cp} 2$ & $4171(8)$ & 2699 (4) & 3270 (3) & $4.3(2) \dagger$ \\
\hline $\mathrm{Cp} 3$ & $3665(9)$ & $1972(4)$ & $3271(3)$ & $4.8(2) \dagger$ \\
\hline $\mathrm{Cp} 4$ & $4741(9)$ & $1519(5)$ & $3043(3)$ & $4.9(2) \dagger$ \\
\hline Cp5 & 5926 (9) & $1984(4)$ & $2884(3)$ & $4.4(2) \dagger$ \\
\hline Cp6 & 6658 (9) & $3372(4)$ & $2947(3)$ & $779(29)$ \\
\hline Cp7 & 3478 (9) & 3318 (4) & 3594 (3) & $848(31)$ \\
\hline Cp8 & $2225(10)$ & $1711(5)$ & $3561(4)$ & $1002(33)$ \\
\hline $\mathrm{Cp} 9$ & $4733(10)$ & $715(5)$ & 3068 (4) & 1009 (35) \\
\hline Cp10 & 7474 (9) & $1731(5)$ & $2698(4)$ & $979(34)$ \\
\hline Cp11 & $854(8)$ & 6492 (4) & $5036(3)$ & $4.1(2) \dagger$ \\
\hline Cp12 & $-349(8)$ & $6374(4)$ & $4605(3)$ & $4.3(2) \dagger$ \\
\hline $\mathrm{Cpl3}$ & $-43(9)$ & 5794 (4) & $4226(3)$ & $4.5(2) \dagger$ \\
\hline Cp14 & $1381(8)$ & $5548(4)$ & $4406(3)$ & $4.0(2) \dagger$ \\
\hline Cp15 & 1931 (9) & $5975(4)$ & $4890(3)$ & $4.1(2) \dagger$ \\
\hline Cpl6 & $870(9)$ & $6976(4)$ & $5593(3)$ & $783(30)$ \\
\hline Cp17 & $-1847(9)$ & $6752(4)$ & $4623(4)$ & $813(29)$ \\
\hline Cpl8 & $-1109(9)$ & $5442(4)$ & $3740(4)$ & 851 (29) \\
\hline Cp19 & 2054 (9) & 4852 (4) & $4205(4)$ & $883(31)$ \\
\hline Cp20 & 3388 (9) & $5860(5)$ & $5264(4)$ & $894(32)$ \\
\hline $\mathrm{Ccl}$ & $1502(8)$ & 2573 (4) & $1529(3)$ & $4.5(2) \dagger$ \\
\hline $\mathrm{Cc} 2$ & $2913(8)$ & 2759 (4) & $1154(3)$ & $4.6(2) \dagger$ \\
\hline $\mathrm{Bc} 3$ & $4004(10)$ & $3378(5)$ & $1498(4)$ & $3.9(2) \dagger$ \\
\hline Bc4 & $3146(9)$ & $3647(4)$ & $2139(4)$ & $3.4(2) \dagger$ \\
\hline Bc5 & 1504 (9) & $3072(5)$ & $2164(4)$ & $4.0(2) \dagger$ \\
\hline Bc6 & $1210(11)$ & $3046(5)$ & $880(4)$ & $5.8(3) \dagger$ \\
\hline Bc7 & 2856 (11) & $3594(5)$ & $854(4)$ & $5.6(3) \dagger$ \\
\hline Bc8 & $2956(10)$ & $4180(5)$ & $1485(4)$ & $4.1(2) \dagger$ \\
\hline Bc9 & $1359(10)$ & $3974(5)$ & $1908(4)$ & $4.3(2) \dagger$ \\
\hline Bcl0 & 342 (11) & $3271(5)$ & $1528(4)$ & $5.2(3) \dagger$ \\
\hline Bell & $1185(10)$ & $3955(5)$ & $1119(4)$ & $4.8(2) \dagger$ \\
\hline $\mathrm{Cc} 21$ & $4076(8)$ & 7199 (4) & $3442(3)$ & $3.8(2) \dagger$ \\
\hline $\mathrm{Cc} 22$ & $2655(8)$ & 7467 (4) & 3077 (3) & $4.2(2) \dagger$ \\
\hline Bc23 & 1543 (I0) & $6770(5)$ & $2853(4)$ & $4.1(2) \dagger$ \\
\hline Bc24 & $2412(9)$ & 5993 (4) & 3077 (4) & $3.6(2) \dagger$ \\
\hline Bc25 & $4059(9)$ & $6311(5)$ & $3490(4)$ & $3.7(2) \dagger$ \\
\hline Bc26 & 4349 (10) & $7521(5)$ & $2735(4)$ & $4.9(2) \dagger$ \\
\hline $\mathrm{Bc} 27$ & $2696(10)$ & $7226(5)$ & $2329(4)$ & $4.8(2) \dagger$ \\
\hline Bc28 & $2587(10)$ & $6282(5)$ & $2326(4)$ & $4.4(2) \dagger$ \\
\hline Bc29 & $4183(10)$ & $5985(5)$ & $2739(4)$ & $3.9(2) \dagger$ \\
\hline Bc30 & $5256(10)$ & $6750(5)$ & $2982(4)$ & $4.5(2) \dagger$ \\
\hline Bc31 & 4354 (10) & $6747(5)$ & 2271 (4) & $4.6(2) \dagger$ \\
\hline Lil & $2786(16)$ & $4920(8)$ & 2409 (6) & $5.9(4) \dagger$ \\
\hline $\mathrm{Li} 2$ & 302 (18) & $6795(9)$ & $1455(7)$ & $7.1(4) \dagger$ \\
\hline $\mathrm{Ol}$ & $1517(7)$ & $6702(5)$ & $766(3)$ & $870(22)$ \\
\hline Cf1 & $2584(17)$ & $7227(6)$ & $553(5)$ & $1182(43)$ \\
\hline $\mathrm{Cf} 2$ & 3820 (15) & 6767 (11) & $329(7)$ & 1749 (71) \\
\hline $\mathrm{Cf} 3$ & $3215(22)$ & $6095(10)$ & $243(10)$ & $2699(103)$ \\
\hline Cf 4 & $1783(14)$ & $6027(7)$ & $481(5)$ & $1193(44)$ \\
\hline $\mathrm{O} 2$ & $-1143(6)$ & 5999 (3) & $1465(4)$ & $863(23)$ \\
\hline Cf5 & $-1635(1)$ & $5620(6)$ & $1966(5)$ & $826(36)$ \\
\hline Cf6 & $-2611(14)$ & $4996(7)$ & $1737(7)$ & $1145(46)$ \\
\hline $\mathrm{Cr} 7$ & $-3038(19)$ & $5227(10)$ & $1144(8)$ & $1882(76)$ \\
\hline Cf8 & $-2097(15)$ & $5781(9)$ & $957(5)$ & $1484(68)$ \\
\hline $\mathrm{O} 3$ & $-751(8)$ & $7642(4)$ & $1414(4)$ & $1163(27)$ \\
\hline CF9 & $-1781(25)$ & $7835(10)$ & $1769(8)$ & $2970(91)$ \\
\hline Cf10 & $-2623(17)$ & $8412(12)$ & $1608(10)$ & $2750(93)$ \\
\hline Cf11 & $-1697(22)$ & $8728(7)$ & 1261 (12) & $2795(120)$ \\
\hline Cf12 & $-961(22)$ & $8122(11)$ & $971(6)$ & $2493(90)$ \\
\hline
\end{tabular}

$\dagger$ Isotropic displacement parameter.
Table 2. Selected distances $(\AA)$ and angles $\left(^{\circ}\right)$ for the $C p^{*}$ carbollide scandium complex

$\mathrm{Cp}^{*} 1$ and $\mathrm{Cp}^{*} 2$ refer to the centroids of the pentamethylcyclopentadienyl ligands, $\mathrm{Cbl}$ and $\mathrm{Cb} 2$ to the centroids of the rings in the carbollide ligands of two $\mathrm{C}$ atoms and three $\mathrm{B}$ atoms bonded to $\mathrm{Sc}$.

\begin{tabular}{|c|c|c|c|}
\hline $\mathrm{Scl}-\mathrm{Cl}$ & $2.280(7)$ & $\mathrm{Si} 2-\mathrm{Me} 4$ & $1.871(10)$ \\
\hline $\mathrm{Scl}-\mathrm{Cbl}$ & 2.126 & Si2-Me5 & $1.843(11)$ \\
\hline $\mathrm{Scl}-\mathrm{Cp} * 1$ & 2.205 & $\mathrm{Si} 2-\mathrm{Me} 6$ & $1.870(10)$ \\
\hline $\mathrm{Sc} 2-\mathrm{C} 2$ & $2.276(7)$ & $\mathrm{Si} 3-\mathrm{Me} 7$ & $1.850(9)$ \\
\hline $\mathrm{Sc} 2-\mathrm{Cb} 2$ & 2.142 & $\mathrm{Si} 3-\mathrm{Me} 8$ & $1.873(10)$ \\
\hline $\mathrm{Sc} 2-\mathrm{Cp}_{\mathrm{p}} * 2$ & 2.192 & $\mathrm{Si} 3-\mathrm{Me} 9$ & $1.805(11)$ \\
\hline $\mathrm{Cl}-\mathrm{Sil}$ & $1.876(7)$ & $\mathrm{Si} 4-\mathrm{Mel0}$ & $1.876(9)$ \\
\hline $\mathrm{Cl}-\mathrm{Si} 2$ & $1.852(8)$ & Si4-Mell & $1.859(10)$ \\
\hline $\mathrm{C} 2-\mathrm{Si} 3$ & $1.870(7)$ & $\mathrm{Si} 4-\mathrm{Me} 12$ & $1.867(9)$ \\
\hline $\mathrm{C} 2-\mathrm{Si} 4$ & $1.862(7)$ & $\mathrm{Li} 2-\mathrm{O} 1$ & $1.917(17)$ \\
\hline Sil-Mel & $1.867(8)$ & $\mathrm{Li} 2-\mathrm{O} 2$ & $1.918(17)$ \\
\hline $\mathrm{Si} 1-\mathrm{Me} 2$ & $1.853(10)$ & $\mathrm{Li} 2-\mathrm{O} 3$ & $1.859(18)$ \\
\hline
\end{tabular}

$\begin{array}{ll}\mathrm{Si}-\mathrm{Me} 2 & 1.853(10) \\ \mathrm{Sil}-\mathrm{Me} 3 & 1.857(10)\end{array}$

$\mathrm{Cp} * 1-\mathrm{Scl}-\mathrm{Cb} 1$

$\mathrm{Cl}-\mathrm{Scl}-\mathrm{Cbl}$

$\mathrm{Cl}-\mathrm{Scl}-\mathrm{Cp}^{* 1}$

137.8

111.2

110.9

$\mathrm{Cp} * 2-\mathrm{Sc} 2-\mathrm{Cb} 2$
$\mathrm{C} 2-\mathrm{Sc} 2-\mathrm{Cb} 2$

$\mathrm{C} 2-\mathrm{Sc} 2-\mathrm{Cp}^{* 2}$

$\mathrm{Si} 1-\mathrm{Cl}-\mathrm{Scl}$

111.0

111.2

$\mathrm{Si2}-\mathrm{Cl}-\mathrm{Scl}$
$\mathrm{Si}-\mathrm{C} 1-\mathrm{Sil}$
$\mathrm{Si} 3-\mathrm{C} 2-\mathrm{Sc} 2$
$\mathrm{Si} 4-\mathrm{C} 2-\mathrm{Sc} 2$
$\mathrm{Si} 4-\mathrm{C} 2-\mathrm{Si} 3$
$\mathrm{Si} 2-\mathrm{C} 1-\mathrm{Sil}$
$\mathrm{Si} 4-\mathrm{C} 2-\mathrm{Si} 3$

120.4 (4)

114.4 (4)

122.9 (3)

$117.6(3)$

113.9 (4)

114.4 (4)

Discussion. This compound crystallizes in space group $P \overline{1}$ with four monomers in the cell, but structurally two monomer anions are loosely connected by one $\mathrm{Li}$ atom into one dimer (Fig. 1), with a $\mathrm{Li}\left(\mathrm{C}_{4} \mathrm{H}_{8} \mathrm{O}\right)_{3}^{+}$counterion; the cell contains two each of these two groups. There is an almost perfect noncrystallographic twofold axis relating the two halves of the anion dimer, passing through $\mathrm{Li}$ and the $\mathrm{Sc} 1-\mathrm{Sc} 2$ midpoint. The two Sc moieties are nearly identical and therefore their average structure will be discussed. The Sc atom is bonded to three centers: the $\mathrm{Cp}^{*}$ centroid, the center of a pentagonal face of the carbollide and a $\mathrm{C}$ atom. The $\mathrm{Sc}-$ center distances are normal (Table 2); $\mathrm{Sc}-\mathrm{C}$ distances vary slightly, being $2.502(22) \AA$ to $\mathrm{Cp}^{*} \mathrm{C}$ atoms, $2.576(22) \AA$ to carbollide $C$ atoms $[2.556(14) \AA$ to carbollide boron atoms] and 2.278 (3) $\AA$ to the $\mathrm{CH}\left[\mathrm{Si}\left(\mathrm{CH}_{3}\right)_{3}\right]_{2} \mathrm{C}$ atoms. Carbollide centroid to $\mathrm{Sc}$ to $\mathrm{Cp}^{*}$ centroid angles are $137.8^{\circ}$, the same as we have found for $\mathrm{Cp}^{*}-\mathrm{Sc}-\mathrm{Cp}$ * angles (Shapiro, Henling, Marsh \& Bercaw, 1990), and the (carbollide or Cp* centroid) $-\mathrm{Sc}-\mathrm{C}$ atom angles are all within $0.2^{\circ}$ of $111.1^{\circ}$. These three large ligands effectively prevent the Sc atom from increasing its coordination number.

The Sc- C-Si angles average $120.1^{\circ}$; the sum of the angles at the $\mathrm{C}$ atom, however, is $354.4^{\circ}$, indicating a relatively small tetrahedral hybridization at the $\mathrm{C}$ atom. The $\mathrm{C}-\mathrm{Si}-$ methyl group angles are all slightly larger than $109.5^{\circ}$ and the methyl group$\mathrm{Si}$-methyl group angles are all slightly smaller [averages $113.7(23)$ and $104.9(10)^{\circ}$ ]. The permethylcyclopentadienyl groups are also normal and regular, with $\mathrm{C}-\mathrm{C}$ (ring) distances of $1.406(16) \AA$ and $\mathrm{C}-\mathrm{C}$ (methyl) distances of 1.518 (18) $\AA$. Interior $\mathrm{C}-\mathrm{C}-\mathrm{C}$ angles differ from $108^{\circ}$ by an average of $1.7^{\circ}$; exterior angles range between 123.6 and $127.3^{\circ}$. 
The carbollide ligands appear well ordered, with relatively small apparent thermal motions. The $\mathrm{C}$ atoms were distinguished from the $\mathrm{B}$ atoms on the basis of their $U_{\text {eq }}$ values and the bond distances - the $\mathrm{C}-\mathrm{C}$ distances are 1.573 (7) $\AA$, whereas the $\mathrm{B}-\mathrm{B}$ distances are $1.760(21) \AA$. C-B distances in the 5-ring are significantly shorter than those to $B$ atoms in the cap [1.646 (16) vs 1.709 (13) $\AA$ ]. Refinement led to acceptable thermal parameters for all 22 atoms of the carbollide groups.

The atoms of the THF groups of the $\mathrm{Li}(\mathrm{THF})_{3}^{+}$ counterion show large displacement parameters, reaching r.m.s. values of $0.8 \AA$, and implying disorder involving non-planar configurations.

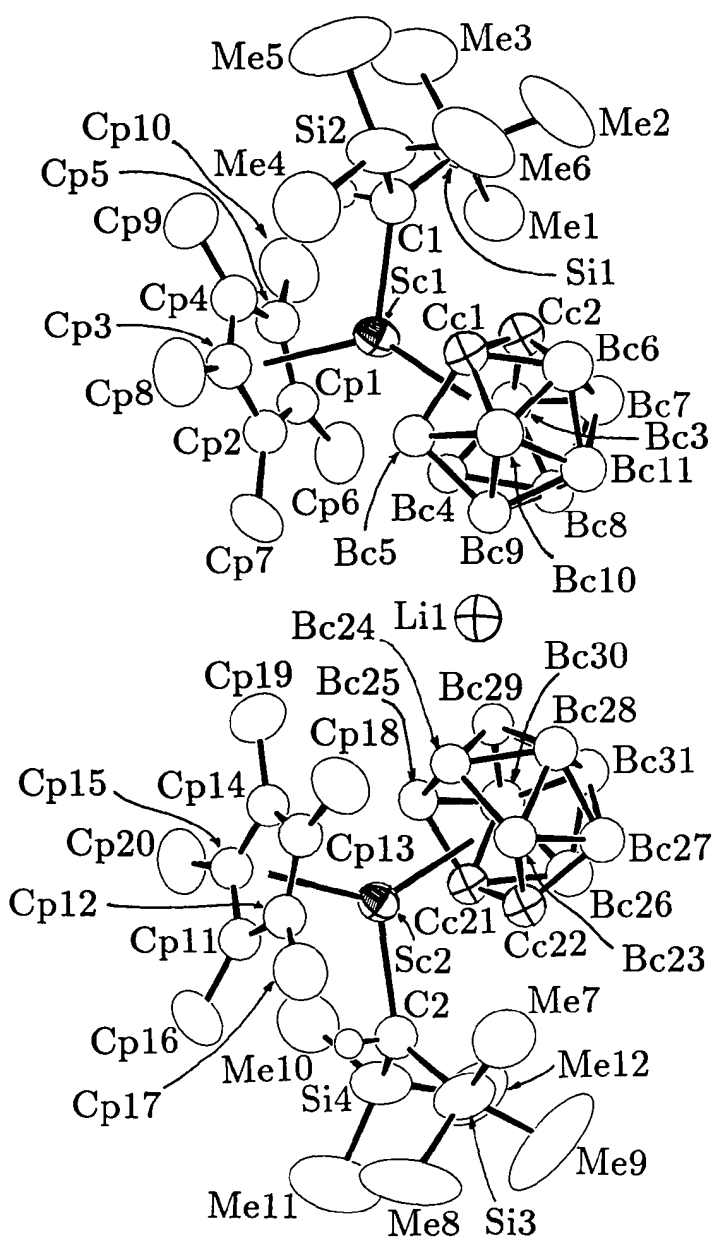

Fig. 1. An ORTEPII (Johnson, 1976) drawing of the two anions and Lil with $50 \%$ probability ellipsoids showing the numbering system. The code is: $\mathrm{Cp}$ (number) $=$ permethylcyclopentadienyl $\mathrm{C}$ atoms; $\mathrm{Me}$ (number) $=$ methyl $\mathrm{C}$ atoms bonded to $\mathrm{Si}$; $\mathrm{Cc}($ number $)=$ carbollide $\mathrm{C}$ atoms; $\mathrm{Bc}($ number $)=$ carbollide $\mathrm{B}$ atoms. Only two $\mathrm{H}$ atoms, those bonded to $\mathrm{Cl}(\mathrm{H} 1)$ and to $\mathrm{C} 2$ (H2) (neither so labeled) are shown.

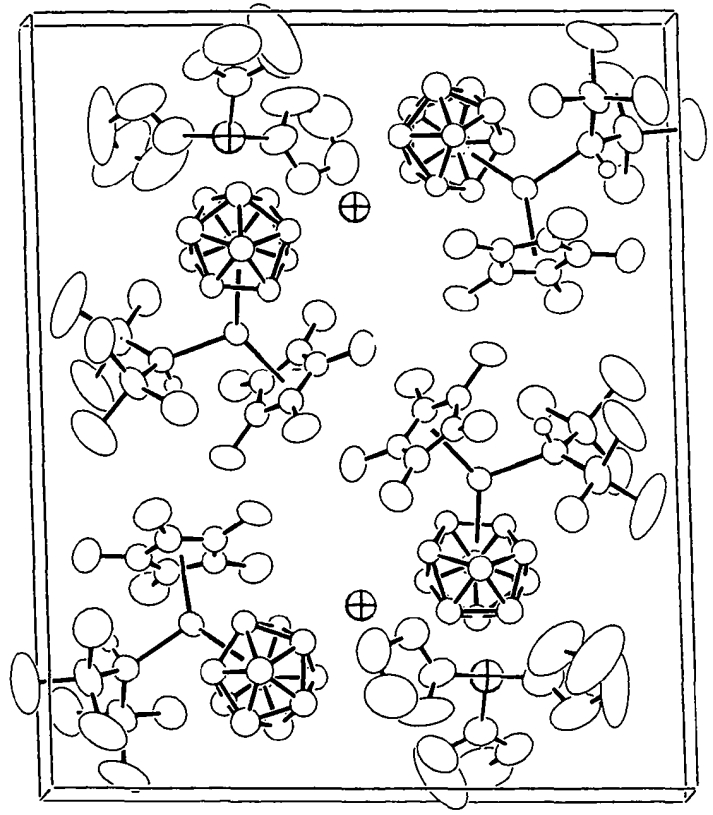

Fig. 2. An ORTEPII (Johnson, 1976) drawing of the contents of one unit cell with the unit cell outlined and projected approximately down the $a$ axis; the $c$ axis is horizontal. Except for those on $\mathrm{Cl}$ and $\mathrm{C} 2, \mathrm{H}$ atoms are omitted. The $\mathrm{Li}$ atoms are shown with principal ellipses marked. $\mathrm{Li} 2$, bonded to the three solvent molecules, interacts slightly with carbollide 2 : $\mathrm{Li} 2-\mathrm{Bc} 272.90$, $\mathrm{Li} 2-\mathrm{Bc} 282.95$ and $\mathrm{Li} 2-\mathrm{Bc} 233.25 \AA$.

The work was supported by the USDOE Office of Basic Energy Sciences (Grant No. DE-FG0385ER113431) and by Exxon Chemicals Americas. GCB thanks NSERCC for a postdoctoral fellowship.

\section{References}

CROMER, D. T. (1974). International Tables for X-ray Crystallography, Vol. IV, pp. 149-151. Birmingham: Kynoch Press. (Present distributor Kluwer Academic Publishers, Dordrecht.)

Cromer, D. T. \& WABER, J. T. (1974). International Tables for $X$-ray Crystallography, Vol. IV, pp. 99-101. Birmingham: Kynoch Press. (Present distributor Kluwer Academic Publishers, Dordrecht.)

Crowther, D. J., BaEnzinger, N. C. \& JoRdan, R. F. (1991). J Am. Chem. Soc. 113, 1455-1457.

DuCHAMP, D. J. (1964). CRYM crystallographic computing system. Am. Crystallogr. Assoc. Meet., Bozeman, Montana. Paper B14, p. 29

JoHNSON, C. K. (1976). ORTEPII. Report ORNL-3794, third revision. Oak Ridge National Laboratory, Tennessee, USA.

ManNing, M. J., KNOBler, C. B., KhatTAR, R. \& HAWTHORNe, M. F. (1991). Inorg. Chem. 30, 2009-2017.

Piers, W. E., Bunel, E. E. \& BercaW, J. E. (1991). J. Organomet. Chem. 47, 51-60.

Shapiro, P. J., Bunel, E., Schaefer, W. P. \& Bercaw, J. E (1990). Organometallics, 9, 867-869, and references therein.

Shapiro, P. J., Henling, L. M., Marsh, R. E. \& Bercaw, J. E. (1990). Inorg. Chem. 29, 4560-4565. Note that in Table IV contained therein, $\mathrm{Si}-\mathrm{Cen} 2$ should be $2.230 \AA$ and $\mathrm{Cen} 1-\mathrm{Sc}-$ Cen 2 should be $138.5^{\circ}$. 